\title{
Association between single nucleotide polymorphisms and sexual precocity in Nellore heifers
}

\author{
Inaê Cristina Regatieri ${ }^{\mathrm{a}}$, Arione Augusti Boligon ${ }^{\mathrm{a}}$, Raphael Bermal Costa ${ }^{\mathrm{a}, \mathrm{c}}$, \\ Fábio Ricardo Pablos de Souza ${ }^{\mathrm{a}, \mathrm{b}}$, Fernando Baldi ${ }^{\mathrm{a}}$, Luciana Takada ${ }^{\mathrm{a}}$, \\ Guilherme Costa Venturini ${ }^{\mathrm{a}}$, Gregório Miguel Ferreira de Camargo ${ }^{\mathrm{a}, \mathrm{c}}$, \\ Gerardo Alves Fernandes Júnior ${ }^{\mathrm{a}}$, Humberto Tonhati ${ }^{\mathrm{a}}$, \\ Henrique Nunes de Oliveira ${ }^{a}$, Lucia Galvão de Albuquerque ${ }^{\mathrm{a}, *}$

\footnotetext{
a Department of Animal Science, Faculdade de Ciências Agrárias e Veterinárias, UNESP - Univ Estadual Paulista, Via de Acesso Prof. Paulo Donato Castellane, s/n, 14884-900, Jaboticabal, São Paulo, Brazil

b Department of Ecology, Zoology and Genetics, Capão do Leão Campus, Institute of Biology - IB, Federal University of Pelotas, 96010-900, Pelotas, RS, Brazil
} \\ c Veterinary Medicine and Animal Science School, Federal University of Bahia UFBA, Salvador, BA, Brazil
}

\section{A R T I C L E I N F O}

\section{Article history:}

Received 22 July 2016

Received in revised form

11 December 2016

Accepted 13 December 2016

Available online 15 December 2016

\section{Keywords:}

Age at first calving

Beef cattle

Genome-wide association

Heifer pregnancy

Linkage disequilibrium

\begin{abstract}
A B S T R A C T
The aim of this study was to determine the extent $\left(r^{2}\right)$ of linkage disequilibrium (LD) in the genome of Nellore cattle, and to examine associations between single nucleotide polymorphisms (SNP) and age at first calving (AFC) and early pregnancy (EP) using a panel of high-density SNPs and data from 1182 Nellore females. A total of 13 contemporary groups (CG) were used consisting of farm, season, and year of birth. For genome-wide association analysis, SNPs with a minor allele frequency (MAF) $<0.05$ and animals with a call rate $<0.90$ were excluded, totaling 431,885 SNPs. For statistical analysis, a linear model was used for AFC and a threshold model for EP. To estimate the significance of the associations for the two traits, the model included the categorical fixed effects of CG, SNPs, and sire. In addition, the polygenic effect was included in the analysis. The additive effects and dominance deviations of Bonferroni-adjusted significant SNPs for AFC and EP were estimated using orthogonal contrasts. The average estimate of $r^{2}$ for all autosomes was 0.18 at a distance of $4.8 \mathrm{~kb}$ and the mean MAF was $0.25 \pm 0.13$. The LD decreased as the distance between markers increased: $0.35(1 \mathrm{~kb})$ to $0.12(100 \mathrm{~kb})$. Eleven significant associations were detected in seven different chromosomes. Seven SNPs were associated with AFC and four were associated with EP. Three SNPs were significant for both traits. The identification of SNPs associated with AFC and EP may contribute for selecting sexually precocious animals.
\end{abstract}

(c) 2016 Elsevier B.V. All rights reserved.

\footnotetext{
* Corresponding author.

E-mail addresses: iregatieri@hotmail.com (I.C. Regatieri), arioneboligon@yahoo.com.br (A.A. Boligon), raphaelbcosta@gmail.com (R.B. Costa), fabiopablos@hotmail.com (F.R.P. de Souza), fernandobaldiuy@gmail.com (F. Baldi), lutakada@gmail.com (L. Takada), venturinigc@gmail.com (G.C. Venturini), gregoriocamargo@hotmail.com (G.M.F. de Camargo), gerardojjunior@yahoo.com.br (G.A. Fernandes Júnior), tonhati@fcav.unesp.br (H. Tonhati), oliveira.hn@gmail.com (H.N. de Oliveira), lgalb@fcav.unesp.br (L.G. de Albuquerque).
} 


\section{Introduction}

The major focus of Zebu breeding programs are traits related to reproductive efficiency, such as sexual precocity. Developing bio-economic models, several authors concluded that reproductive traits are economically more important than growth traits (Brumatti et al., 2011; Krupa et al., 2005; Wolfova et al., 2005). In this respect, studies have shown that an increase in productivity ( $\mathrm{kg}$ live weight sold/hectare/year) can be achieved with a reduction in the slaughter age of heifers, associated with an earlier age of heifers at first breeding (Beretta et al., 2001, 2002a,b; Pötter et al., 1998, 2000).

Age at first calving (AFC) and early pregnancy (EP) are related to the efficiency and profitability of beef production. Although AFC is easily obtained and is observed early during the animal's life, some breeders delay the start of the breeding season by predetermining a specific weight and/or age, impairing the identification of precocious animals and reducing genetic variability in this trait (Dias et al., 2004a). In addition, the fact that only animals that calve are included in the analyses and the low heritability estimates (Boligon et al., 2010; Dias et al., 2004b; Grossi et al., 2009; Mercadante et al., 2000; Pereira et al., 2000, 2005; Regatieri et al., 2012) result in a poor response to selection.

In an attempt to overcome the difficulties encountered when AFC is used as a selection criterion, EP has been employed in genetic breeding programs. According to Shiotsuki et al. (2009), EP is defined by the observation of a heifer that conceived and calved after she had been exposed to a bull during the breeding season. This definition results in a binary response of the trait (success or failure), a fact that permits the inclusion of data from all females in the analyses. In addition, this trait has greater heritabilities (0.50-0.73) for heifers exposed to bulls for the first time between 14 and 18 months of age (Boligon and Albuquerque, 2011; Eler et al., 2002, 2004; Silva et al., 2005; Van Melis et al., 2010), thus permitting a rapid response to selection.

Reproductive traits have quantitative genetic variation and the expression is influenced by some genes or a series of genes (quantitative trait loci, QTL). According to Höglund et al. (2009), the identification of a QTL for female reproductive traits can increase the response to selection. These genes can be identified based on the linkage disequilibrium (LD), which is calculated as the squared correlation of allele frequencies $\left(r^{2}\right)$ at a given locus (Hayes, 2009). Molecular markers, called single nucleotide polymorphisms (SNP), are commonly used for the detection of QTL due to the ease of genotyping and the fact that these polymorphisms are present throughout the genome (Hayes et al., 2006).

The 50k SNP panels have been used in beef cattle to determine associations of SNPs with reproductive traits. Zhang et al. (2010) reported associations between several SNPs and age at puberty in Brahman females. Similarly, Hawken et al. (2012), working with Brahman Tropical Composite cattle, observed associations of SNPs with postpartum anestrus interval and the occurrence of postpartum ovulation before weaning. Using part of the data from the study of Hawken et al. (2012), Fortes et al. (2012) identified SNPs and chromosome regions that are directly associated with age at puberty of females and scrotal circumference in bulls. There have been some studies related to reproductive traits in zebu cattle such as: genome-wide association studies using 777k SNP panels (Irano et al., 2016; Nascimento et al., 2015; Costa et al., 2015), candidate gene/SNP studies (Fortes et al., 2013a,b), and combinations of methodologies (SNP association and gene expression; Fortes et al., 2014). The use of these technologies is being developed especially in tropical regions due to the importance of female performance in beef production profitability.

Genome-wide association studies using high-density panels are still scarce in zebu cattle. The objective of the present study, therefore, was to identify regions of LD in the bovine genome, and determine the presence of genetic markers that are associated with age at first calving and early pregnancy in Nellore cattle.

\section{Materials and methods}

A total of 1182 records of Nellore females born in 2007 and 2008 from 131 sires, which belonged to Agropecuária Jacarezinho Ltda. (Valparaíso, São Paulo - Brazil), were used. Genomic DNA was extracted from hair follicles obtained from the tail switch of females using the phenol/chloroform/isoamyl alcohol method (Sambrook and Fristch, 1989). Genotyping was performed using the highdensity BovineHD BeadChip (Illumina, San Diego, CA, USA - 777,962 SNPs) according to the Illumina Infinium ${ }^{\circledR}$ II Assay Multi-Sample protocol in a HiScan ${ }^{\mathrm{TM}}$ SQ System. The consistency of the genomic data was confirmed using the Genome Studio program. Bovine autosomes (BTA, $n=29$ ) were considered for analysis and the genotypes were defined as AA and BB (homozygous), AB (heterozygous), and NA (not identified). The sex chromosome was not included in the analysis.

A total of 824 and 11,389 markers were excluded due to an unknown genome position and low mean cluster intensity ( $A B, A A$ or $B B$ mean $<0.3$ ), respectively. In addition, 21,709 markers present on the sex chromosomes were also eliminated. Only markers with a minor allele frequency (MAF) $>0.05$ were considered for analysis. In addition, only markers with excess heterozygosity $<0.30$ were analyzed and animals with a call rate $<0.90$ were excluded.

The LD between two SNPs was calculated based on the $r^{2}$ measure (Hill and Robertson, 1968) as follows:

$r^{2}=\frac{(\text { freq. } . A B * \text { freq. } a b-\text { freq. } A b * \text { freq. } a B)^{2}}{(\text { freq. } A * \text { freq. } a * \text { freq. } B * \text { freq. } b)}$

Where freq.A, freq.a, freq.B and freq.b are the frequencies of alleles $A, a, B$ and $b$, respectively, and freq.AB, freq.ab, freq. $a B$ and freq. $A b$ are the frequencies of haplotypes $A B$, $a b, a B$ and $A b$, respectively, in the population. If the two loci are independent, the expected frequency of genotype $A B$ (freq. $A B$ ) is calculated as the product between freq.A and freq. B. A freq.AB that is greater or less than the expected value indicates that these two loci tend to segregate together and are in $\mathrm{LD}$. The measure of $\mathrm{LD}\left(r^{2}\right)$ was calculated for all pairs of SNP markers of each chromosome using the SnppldHD program (Sargolzaei, M., University 
of Guelph, Canada), and the pedigree data were used to construct the relationship matrix.

The following two traits were studied: AFC defined as the age of the female at the time of first calving, and EP defined as a result (2) of a heifer conceiving and calving at less than 31 months of age or as failure (1) of a heifer to calve or calve at more than 31 months of age after breeding at 14-16 months of age. Thirteen contemporary groups (CG) were formed, with an average number of 90 animals per group for AFC and EP. The CG were defined by farm, year, and season of birth. For AFC, records outside the interval of the mean of the $C G \pm 3$ standard deviations were excluded. For EP, CG without phenotypic variability were eliminated.

Age at first calving ranged from 748 to 1,253 days, with a mean of $1049 \pm 139.8$ days. The percentage of precocious (success) and non-precocious (failure) females was $29.31 \%$ and $70.69 \%$, respectively. A normal distribution and linear model were assumed for AFC. The PROC MIXED procedure and Fisher-Snedecor (F-distribution) test were used to estimate the significance of the associations and SNP effects in the SAS software (SAS Institute, Cary NC, USA). A binomial distribution and nonlinear model were assumed for EP. The PROC GENMOD procedure and chi-squared test were used for the association studies.

To estimate the significance of the associations ( $P$-value) for the two traits, genotypes $A A, A B$ and $B B$ were defined as 0,1 and 2, respectively, and the model included the CG and genotypes as categorical fixed effects. The polygenic effect was also included in the analysis to account for residual genetic variance not explained by the SNP. The model can be written as:

$y=X b+Z u+W g+e$,

where $y$ is the vector of phenotypes; $X$ is an incidence matrix of systematic effects; $b$ is the vector of systematic effects; $Z$ is an incidence matrix of polygenic effects; $u$ is a random vector of polygenic effects of all individuals in the pedigree; $W$ is a matrix ( $\mathrm{n} \times \mathrm{p}$ ) consisting of the genotypes of $p$ SNP markers for each animal $n ; g$ is a random vector of SNP effects; $e$ is a vector of residual effects.

Bonferroni correction was applied to maintain the error rate at a level of $5 \%$, and a significance threshold (p-value) for significant associations of less than $1.16 \times 10^{-7}$ was adopted. The additive effects and dominance deviations of Bonferroni-adjusted significant SNPs were tested using PROC GLM procedure of the SAS software (SAS Institute, Cary NC, USA) and orthogonal contrasts. A Manhattan plot was constructed for greater visualization of the peaks of SNPs that were significantly associated with the traits studied. For this purpose, $-\log _{10}(P$-value $)$ was plotted as a function of the position of the SNPs on each chromosome.

The false discovery rate (FDR) was estimated using the following equation (Benjamini and Hochberg, 1995):

$F D R=n P / k$

Where $n$ is the total number of SNPs included in the association study, $P$ is the level of significance $(\alpha)$ used, and $k$ is the number of SNPs significantly associated with the trait at the $\alpha$ level used.
A subjective criterion based on the peaks of significant SNPs identified in the Manhattan plots was used to determine regions containing potential QTL. According to Sahana et al. (2010), a given region of a chromosome can be defined as a QTL when it contains many SNPs that are significantly associated with one or more traits. Therefore, a region harboring significant SNPs $(-\log 10(p)>3.5)$ concentrated at a specific position of the chromosome was defined as a region containing potential QTL. Significant SNPs found isolated in a given region of the chromosome were excluded from the definition of QTL region due to the greater risk of being false positive.

\section{Results and discussion}

\subsection{Linkage disequilibrium}

A total of 431,885 ( $\approx 55.51 \%)$ SNPs passed the exclusion criteria and were used in the final analyses. This subset of markers comprised 115,511.954 Mb of the genome. The mean distance between markers was $4.8 \pm 2.9 \mathrm{~kb}$. A total of $8,732,131$ synthetic SNP pairs (combination of SNP pairs on the same chromosome) were analyzed for all autosomes. The chromosomes varied in size, with BTA25 being the smallest chromosome ( $42.8 \mathrm{Mb})$ and BTA1 being the largest chromosome (158.2 Mb; Table 1).

The average $\mathrm{r}^{2}$ for all autosomes was 0.18 (range: 0.003-0.24; Table 1). This extent of LD was less than that reported by McKay et al. (2007) for Nellore cattle (0.06-0.69 depending on the chromosome) using 2670 SNPs. Silva et al. (2010) obtained an average LD similar to that observed in the present study $\left(r^{2}=0.21\right)$ for Gyr sires using a 50k chip.

There are few studies investigating LD in Bos indicus. The present study was performed using part of the animals used by Espigolan et al. (2013) and the results were very similar to that previously reported. According to the literature, $r^{2}$ values for taurine animals are generally greater than those obtained for Zebu animals. McKay et al. (2007) obtained an average $r^{2}$ of 0.37 and 0.56 for Bos indicus and Bos taurus, respectively. This difference can be explained by the inverse relationship between population size and LD. A reduction in the Bos taurus population was observed after domestication (Goddard and Hayes, 2009) and after the intense selection applied to some breeds. Sargolzaei et al. (2008), using a 10k chip for genotyping Holstein cattle, found an average $r^{2}$ that was greater than that observed in the present study (0.31). Using a 50k chip, Lu et al. (2012) reported greater mean $r^{2}$ values (for distances of up to $30 \mathrm{~kb}$ ) for Bos Taurus (0.29 and 0.22 for Angus and Charolais cattle, respectively) but, for Bos taurus $x$ Bos taurus crossbred animals, a similar value was observed to that in the present study (0.21). In the research of Espigolan et al. (2013), however, there was a $r^{2}(0.17)$ that was similar to that in the present research using another sample of Nelore animals.

The mean MAF in the present study was $0.25 \pm 0.13$. This mean MAF was similar to that reported by Khatkar et al. (2008) for Holstein-Friesian cattle (0.286 \pm 0.0013$)$. The MAF in the present study was also similar to those reported by Matukumalli et al. (2009) for taurine breeds 
Table 1

Summary of the SNPs analyzed and average linkage disequilibrium $\left(r^{2}\right)$ between adjacent synthetic markers obtained for each chromosome (BTA).

\begin{tabular}{|c|c|c|c|c|c|c|}
\hline BTA & a Size (Mb) & ${ }^{\mathrm{b}} \mathrm{SNP}(\mathrm{n})$ & ${ }^{\mathrm{c}}$ Mean distance $\pm \mathrm{SD}(\mathrm{kb})$ & ${ }^{\mathrm{d}}$ Mean $r^{2} \pm \mathrm{SD}$ & ${ }^{\mathrm{f}}$ Median $r^{2}$ & ${ }^{\mathrm{e}}$ Mean $\mathrm{MAF} \pm \mathrm{SD}$ \\
\hline 1 & 158.2 & 27,129 & $4.9 \pm 2.9$ & $0.13 \pm 0.23$ & 0.017 & $0.25 \pm 0.13$ \\
\hline 2 & 136.8 & 22,898 & $4.9 \pm 2.9$ & $0.19 \pm 0.25$ & 0.077 & $0.25 \pm 0.13$ \\
\hline 3 & 121.4 & 22,023 & $4.9 \pm 2.9$ & $0.20 \pm 0.25$ & 0.085 & $0.25 \pm 0.13$ \\
\hline 4 & 120.6 & 19,723 & $4.9 \pm 2.9$ & $0.19 \pm 0.25$ & 0.074 & $0.25 \pm 0.13$ \\
\hline 5 & 121.1 & 19,353 & $4.9 \pm 2.9$ & $0.21 \pm 0.27$ & 0.093 & $0.26 \pm 0.13$ \\
\hline 6 & 119.4 & 22,784 & $4.9 \pm 2.9$ & $0.20 \pm 0.25$ & 0.086 & $0.26 \pm 0.13$ \\
\hline 7 & 112.6 & 19,537 & $4.9 \pm 2.9$ & $0.20 \pm 0.26$ & 0.081 & $0.25 \pm 0.13$ \\
\hline 8 & 113.3 & 21,406 & $5.0 \pm 2.9$ & $0.21 \pm 0.26$ & 0.102 & $0.26 \pm 0.13$ \\
\hline 9 & 105.6 & 19,848 & $4.9 \pm 2.9$ & $0.20 \pm 0.26$ & 0.083 & $0.26 \pm 0.13$ \\
\hline 10 & 104.3 & 16,711 & $4.8 \pm 2.9$ & $0.18 \pm 0.25$ & 0.065 & $0.25 \pm 0.13$ \\
\hline 11 & 107.2 & 17,809 & $4.8 \pm 2.9$ & $0.19 \pm 0.26$ & 0.071 & $0.25 \pm 0.13$ \\
\hline 12 & 91.1 & 14,866 & $4.9 \pm 2.9$ & $0.19 \pm 0.25$ & 0.076 & $0.25 \pm 0.13$ \\
\hline 13 & 84.2 & 13,824 & $5.0 \pm 2.9$ & $0.20 \pm 0.25$ & 0.085 & $0.25 \pm 0.13$ \\
\hline 14 & 83.9 & 16,198 & $5.0 \pm 2.9$ & $0.19 \pm 0.24$ & 0.081 & $0.26 \pm 0.13$ \\
\hline 15 & 85.2 & 14,238 & $4.9 \pm 2.9$ & $0.19 \pm 0.25$ & 0.073 & $0.25 \pm 0.13$ \\
\hline 16 & 81.7 & 14,242 & $4.9 \pm 2.9$ & $0.24 \pm 0.18$ & 0.077 & $0.25 \pm 0.13$ \\
\hline 17 & 75.1 & 14,014 & $4.9 \pm 2.9$ & $0.20 \pm 0.26$ & 0.072 & $0.24 \pm 0.13$ \\
\hline 18 & 65.9 & 11,125 & $4.8 \pm 2.9$ & $0.16 \pm 0.23$ & 0.055 & $0.25 \pm 0.13$ \\
\hline 19 & 64.0 & 9689 & $4.9 \pm 2.9$ & $0.21 \pm 0.26$ & 0.090 & $0.24 \pm 0.13$ \\
\hline 20 & 71.9 & 12,240 & $4.8 \pm 2.9$ & $0.18 \pm 0.25$ & 0.069 & $0.25 \pm 0.13$ \\
\hline 21 & 71.6 & 12,356 & $4.9 \pm 2.9$ & $0.18 \pm 0.24$ & 0.068 & $0.25 \pm 0.13$ \\
\hline 22 & 61.3 & 10,100 & $4.8 \pm 2.9$ & $0.17 \pm 0.24$ & 0.067 & $0.25 \pm 0.13$ \\
\hline 23 & 52.5 & 9054 & $4.9 \pm 2.9$ & $0.17 \pm 0.24$ & 0.061 & $0.26 \pm 0.13$ \\
\hline 24 & 62.3 & 10,899 & $4.9 \pm 2.9$ & $0.17 \pm 0.24$ & 0.060 & $0.25 \pm 0.13$ \\
\hline 25 & 42.8 & 7315 & $4.9 \pm 2.9$ & $0.17 \pm 0.23$ & 0.063 & $0.24 \pm 0.13$ \\
\hline 26 & 51.6 & 9219 & $4.8 \pm 2.9$ & $0.16 \pm 0.23$ & 0.062 & $0.24 \pm 0.13$ \\
\hline 27 & 45.4 & 7651 & $4.9 \pm 2.9$ & $0.10 \pm 0.18$ & 0.024 & $0.25 \pm 0.13$ \\
\hline 28 & 46.2 & 7547 & $4.8 \pm 2.9$ & $0.03 \pm 0.08$ & 0.004 & $0.26 \pm 0.13$ \\
\hline 29 & 51.2 & 8087 & $4.9 \pm 2.9$ & $0.003 \pm 0.02$ & 0.001 & $0.24 \pm 0.13$ \\
\hline
\end{tabular}

SNP: Single nucleotide polymorphism; MAF: Minor allele frequency; SD: Standard deviation.

a Size of the chromosome.

b Number of SNPs analyzed per chromosome.

c Mean distance between SNPs analyzed.

d Measures of linkage disequilibrium $\left(r^{2}\right)$ per chromosome.

e Measures of linkage disequilibrium $\left(r^{2}\right)$ per chromosome.

f Mean MAF per chromosome.

such as Charolais (0.26), Holstein (0.26) and Angus (0.25) cattle, but was greater than those reported for the Zebu breeds such as Brahman (0.18), Gyr (0.19) and Nellore (0.19). The MAF in the study of Espigolan et al. (2013) was similar to that in the present study for the Nellore breed (0.25).

A high percentage of SNPs (58\%) had an MAF that was greater than 0.2 (Fig. 1). Chromosomes 2, 7, 11, 12, 17, 25, 26 , and 29 had a large proportion of SNPS with a MAF $<0.10$, whereas this proportion was less for chromosomes $1,5,6$, $8,9,23$, and 28 .

To determine the decrease in LD with increasing physical distance between markers, the SNPs were classified into distance intervals. Using this approach, an average $r^{2}$ value was estimated for each distance class per autosome (Fig. 2) and for the whole genome (Table 2).

A reduction in LD was observed with increasing physical distance between markers as expected (Fig. 2). Moderate $r^{2}$ values (0.21-0.35) were obtained for distances of less than $30 \mathrm{~kb}$. When the distance between markers increased from 30 to $100 \mathrm{~kb}, r^{2}$ values decreased $(0.12-0.18)$.

The reduction in LD with increasing physical distance between markers can be explained by the fact that the recombination rate is less at short distances and the levels of LD are, therefore, greater. Similar results have been reported by Espigolan et al. (2013) where $r^{2}$ values of
Table 2

Measures of linkage disequilibrium $\left(r^{2}\right)$ according to distance interval.

\begin{tabular}{lll}
\hline Distance $(\mathrm{kb})$ & Mean $r^{2} \pm \mathrm{SD}$ & Median $r^{2}$ \\
\hline $0-0.99$ & $0.35 \pm 0.34$ & 0.22 \\
$1-1.99$ & $0.34 \pm 0.31$ & 0.20 \\
$2-2.99$ & $0.32 \pm 0.30$ & 0.19 \\
$3-3.99$ & $0.31 \pm 0.30$ & 0.18 \\
$4-4.99$ & $0.30 \pm 0.29$ & 0.16 \\
$5-9.99$ & $0.28 \pm 0.28$ & 0.14 \\
$10-19.99$ & $0.24 \pm 0.26$ & 0.11 \\
$20-29.99$ & $0.21 \pm 0.25$ & 0.09 \\
$30-39.99$ & $0.18 \pm 0.23$ & 0.07 \\
$40-49.99$ & $0.17 \pm 0.22$ & 0.06 \\
$50-59.99$ & $0.15 \pm 0.21$ & 0.06 \\
$60-69.99$ & $0.14 \pm 0.20$ & 0.06 \\
$70-79.99$ & $0.13 \pm 0.20$ & 0.05 \\
$80-89.99$ & $0.13 \pm 0.19$ & 0.04 \\
$90-100$ & $0.12 \pm 0.19$ & 0.04 \\
\hline
\end{tabular}

SD: Standard deviation.

$0.34-0.20$ were observed at distances of $0-30 \mathrm{~kb}$ in Nellore animals, and this decreased to $0.18-0.11$ at distances of $30-100 \mathrm{~kb}$. A reduction in LD with increasing distance between markers has also been reported by De Roos et al. (2008) for different breeds (Holstein-Friesian, Jersey and Angus). In that previous study, $r^{2}$ values decreased from 0.22 to 0.35 (distances of up to $40 \mathrm{~kb}$ ) to $0.14-0.16$ (distances of $80-100 \mathrm{~kb}$ ). Similar results were observed by Lu 

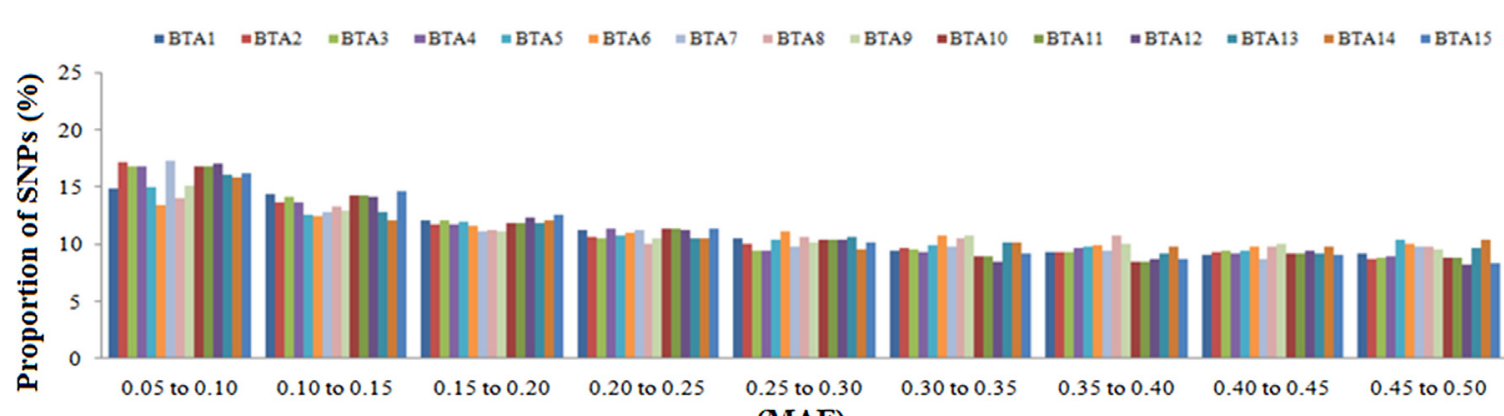

(MAF)

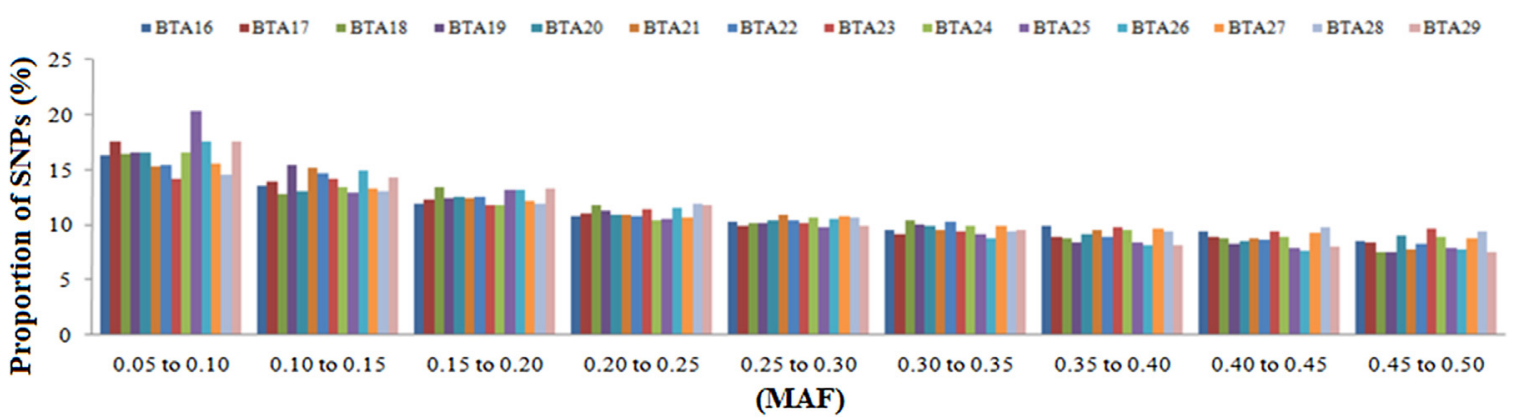

Fig. 1. Mean proportion of SNPs (\%) according to minor allele frequency (MAF) class for bovine chromosomes (BTA) 1-29.

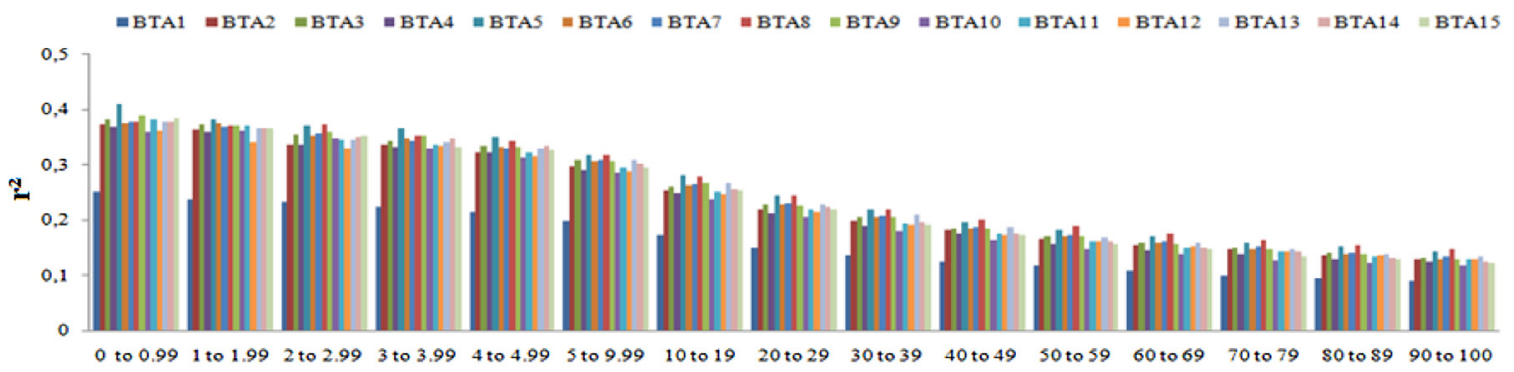

Distance between markers (kb)

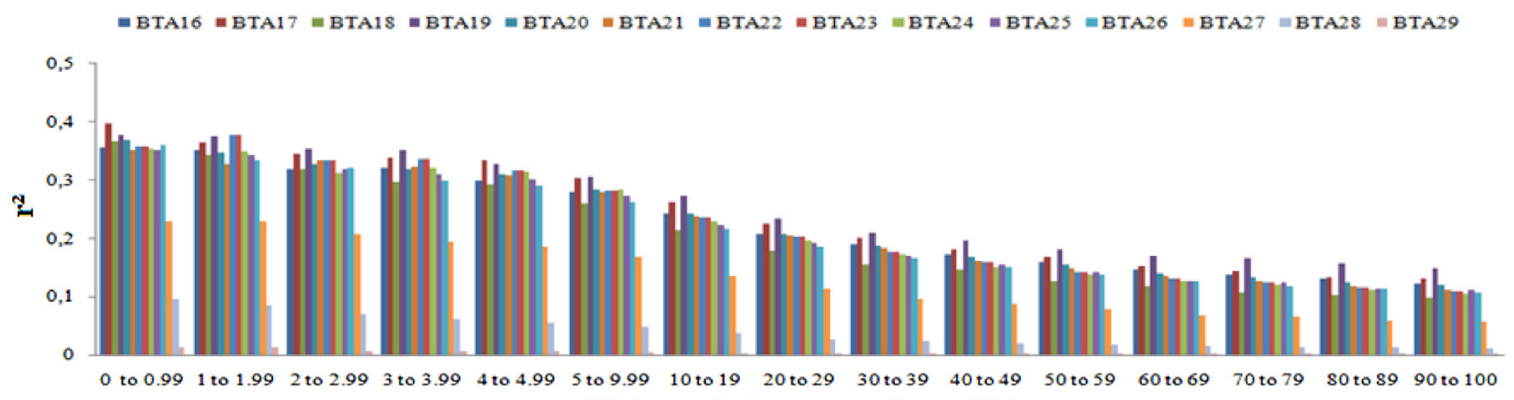

Distance between markers (kb)

Fig. 2. Average linkage disequilibrium $\left(r^{2}\right)$ as a function of distance between markers for bovine chromosomes (BTA) 1-29.

et al. (2012) where there was a reduction in average LD from 0.29 to 0.19 (Angus), from 0.22 to 0.12 (Charolais) and from 0.21 to 0.11 (Bos taurus $x$ Bos taurus crossbreed) when the distance increased from $030 \mathrm{~kb}$ to $70-100 \mathrm{~kb}$. In contrast to the present study, a greater $\operatorname{LD}\left(r^{2}=0.58\right)$ has been described by Sargolzaei et al. (2008) for distances between SNPs of up to $100 \mathrm{~kb}$ in Holstein cattle. Only at distances of
$100 \mathrm{~kb}$ to $1 \mathrm{Mb}$ was there a reduction in the extent of LD $\left(r^{2}=0.15-0.02\right)$.

\subsection{Association studies}

The SNPs significantly associated to AFC and EP at a level of significance of $5 \%, 1 \%$ and $0.1 \%$ were detected on all chromosomes (Table 3). The number of significant SNPs 
Table 3

Number of significant SNPs (N), mean $P$-values (in parentheses) and false discovery rate at three levels of significance $(\alpha)$.

\begin{tabular}{llllll}
\hline Significance $(\alpha)$ & AFC & & EP & \\
\cline { 2 - 3 } \cline { 5 - 6 } \cline { 5 - 6 } & $\mathrm{N}$ & FDR $(\%)$ & & $\mathrm{N}$ & FDR $(\%)$ \\
\hline $5 \%$ & $35.750(0.022)$ & 60 & & $43.926(0.021)$ & 49 \\
$1 \%$ & $9.594(0.004)$ & 45 & & $12.951(0.004)$ & 33 \\
$0.10 \%$ & $1.630(0.0004)$ & 27 & & $2.349(0.0004)$ & 18 \\
\hline
\end{tabular}

AFC: Age at first calving; EP: Early pregnancy; FDR: False discovery rate.

at the $5 \%$ level corresponds to approximately $8.3 \%$ (AFC) and $10.2 \%$ (EP) of all SNPs used in the association studies. This number of significant SNPs per chromosome was similar (6.8\%) to that reported by Zhang et al. (2010) where age at puberty was analyzed in Brahman cattle $(P<0.05)$ using the Bovine SNP50 BeadChip. Fortes et al. (2011) used the same chip and observed that 5.8\% (Tropical Composite) and $6.7 \%$ (Brahman) of SNPs were significant $(P<0.05)$ for 22 traits, including age at puberty.

The false-positive rate was greater for AFC than for EP. A greater FDR has been described by Pryce et al. (2010) for pregnancy in the first 42 days after breeding in Holstein cattle at a significance level of $0.1 \%(F D R=53 \%)$. At the same level, Hawken et al. (2012) reported FDR for age at puberty of Brahman animals (FDR $=26 \%$ ) similar to findings in the present study.

A large number of SNPs significantly associated with the traits indicated regions potentially containing QTL for AFC and EP. For AFC (Fig. 3), 18 chromosomes exhibited SNPs with a significant effect (Chromosomes 2-11, 16, 17, 19-26), according to the subjective criterion used for the detection of regions potentially containing QTL. The most apparent peaks indicating potential QTL were found on chromosomes 4 (from 21.1 to $21.4 \mathrm{Mb}$ ), 17 with two peaks (from 19.1 to $25.6 \mathrm{Mb}$ and from 58.3 to $67.9 \mathrm{Mb}$ ), and 19 (from 58.7 to $61.7 \mathrm{Mb}$ ).

For EP (Fig. 4), 18 chromosomes also exhibited peaks of significant SNPs (Chromosomes 2-11, 14, 16, 17, 19, $20,23-26)$, using the same subjective criterion. The most apparent SNPs were found on chromosomes 6 (from 86.4 to $89.4 \mathrm{Mb}$ and from 99.8 to $108.8 \mathrm{Mb}$ ), 8 (from 57.7 to 58.4 $\mathrm{Mb}$ and from 104.0 to $105.8 \mathrm{Mb}$ ), 17 with two peaks (from 19.1 to $25.6 \mathrm{Mb}$ and from 65.7 to $71.8 \mathrm{Mb}$ ), and 19 (from 58.7 to $61.7 \mathrm{Mb})$.

After Bonferroni correction for multiple tests (p-value threshold $=1.16 \times 10^{-7}$ ), seven chromosomes (Fig. 3 and 4 ) exhibited SNPs that were significantly associated with AFC (7 SNPs) and EP (four SNPs; Table 4).

Three SNPs (BovineHD0100003126, BovineHD2100019377, and BovineHD2200012994) located on chromosomes BTA1, BTA21 and BTA22 (Fig. 3 and 4) significantly influenced both traits. Chromosome BTA21 contained two SNPs related to EP. The greatest significance detected for the two traits $\left(P\right.$-value $=4.27 \times 10^{-18}$ for $\mathrm{AFC}$ and $P$ value $=3.45 \times 10^{-17}$ for $E P$ ) was observed for the same SNP (BovineHD0100003126), located on chromosome BTA1.

Using the MapViewer - Build 6.1 (NCBI, 2013) program for cattle, the SNPs for AFC and EP that were significant at the Bonferroni-adjusted significance level were found to be close to various known genes (Table 4). The distance of the SNP until the beginning or until the end of the gene, according to the position of the polymorphism on the chromosome, is given in base pairs. A distance of zero indicates that the SNP is located within the region of the gene. The SNPs close to seven genes were detected in the genome, with three of these genes being shared by the two traits.

Among the genes located closest to the significant SNPs after Bonferroni correction, the APP gene encodes a cell surface receptor and transmembrane precursor in the central nervous system of humans (Venkataramani et al., 2010). The LOC100140224 has a role in the reproductive system, it functions in germ cell development in mice (Krotz et al., 2009). Other genes that are also involved in the central nervous and reproductive systems have been found to be associated with puberty and fertility traits by Fortes et al. (2011, 2012) and Hawken et al. (2012) in Brahman and Tropical Composite cattle.

Some of the genes identified are involved with specific functions in the organism. The TMEM17 gene is involved in the formation of cilia, structures found in many cells of the organism, with a special role in sperm. Sperm cells with cilia malformation reduce the fertility rates. The identification of a gene related to cilia formation indicates that pregnancy success may be related to male fertility.

The LOC785475 gene is involved in cell development. In humans, this gene is found in the pseudoautosomal region of the sex chromosomes and it has been suggested to be associated with male infertility (McElreavey and Fellous, 1999). Other genes have a role in the formation of nucleosomes (LOC526064) and histone methylation (SETD3), processes that are related to DNA metabolism. Interestingly, the SETD3 gene was emphasized in this previous study. This finding suggests that this gene influences many other genes that may be packaged by modified histones and may have the expression suppressed. The epigenetics considerably affects the phenotype of reproductive traits in cattle, as demonstrated by Funston and Summers (2013). Further studies using chromatin immunoprecipitation are needed to identify whether these regions can aid the genetic evaluations.

The ARFGEF3 gene is related to bone cells physiology. Other growth-related genes that influence reproductive traits have been identified by Hawken et al. (2012), Fortes et al. (2013a,b) and Costa et al. (2015). However, with the sequencing of genomes it became evident that genes have multiple functions and can function in different, still unknown metabolic pathways. An example is the sheep FECB gene which is associated with ovulation rate. This gene was first described to be involved in bone development (Drouilhet et al., 2009) and its function in reproduction was discovered later. Thus, studies on the functions of genes are important to elucidate the role of specific genes in the development of the organism. Moreover, there is an association between bone turnover and menarche in girls (Eastell, 2005). These findings, in humans, corroborate findings in the present study related to the ARFGEF3 gene and also previous and similar research with cattle and sheep.

It is interesting to note that other genome-wide studies using part of the animals of the present study (Irano et al., 


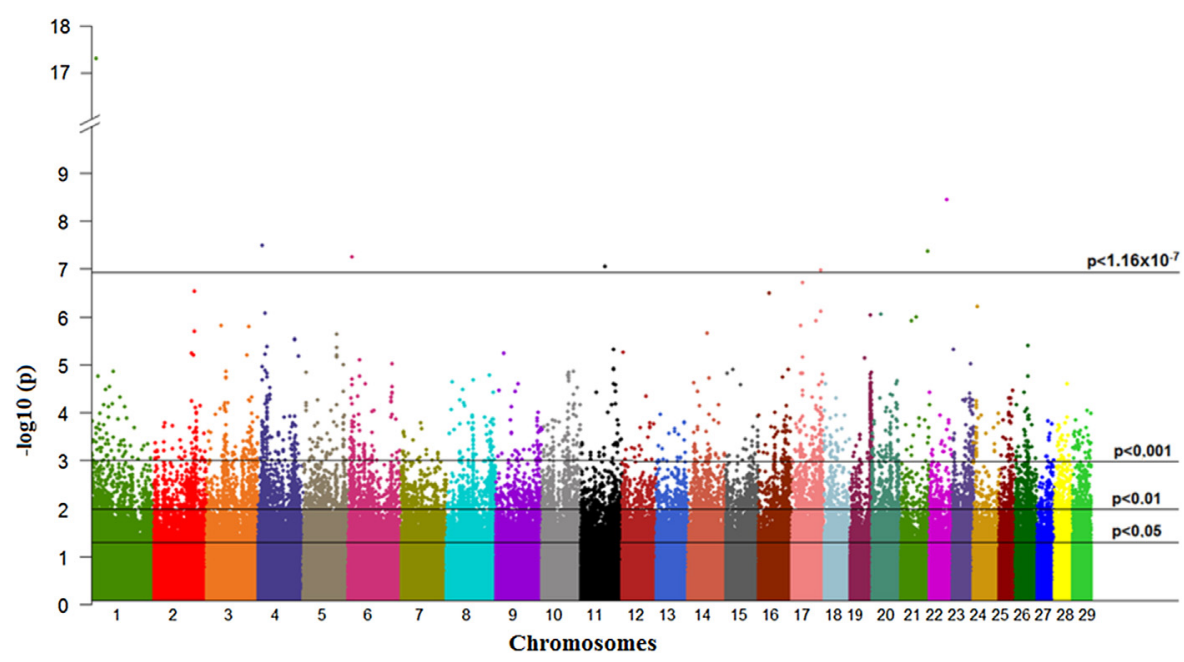

Fig. 3. Manhattan plot for age at first calving; $-\log 10(\mathrm{p}$-value) is plotted as a function of SNPs per chromosome.

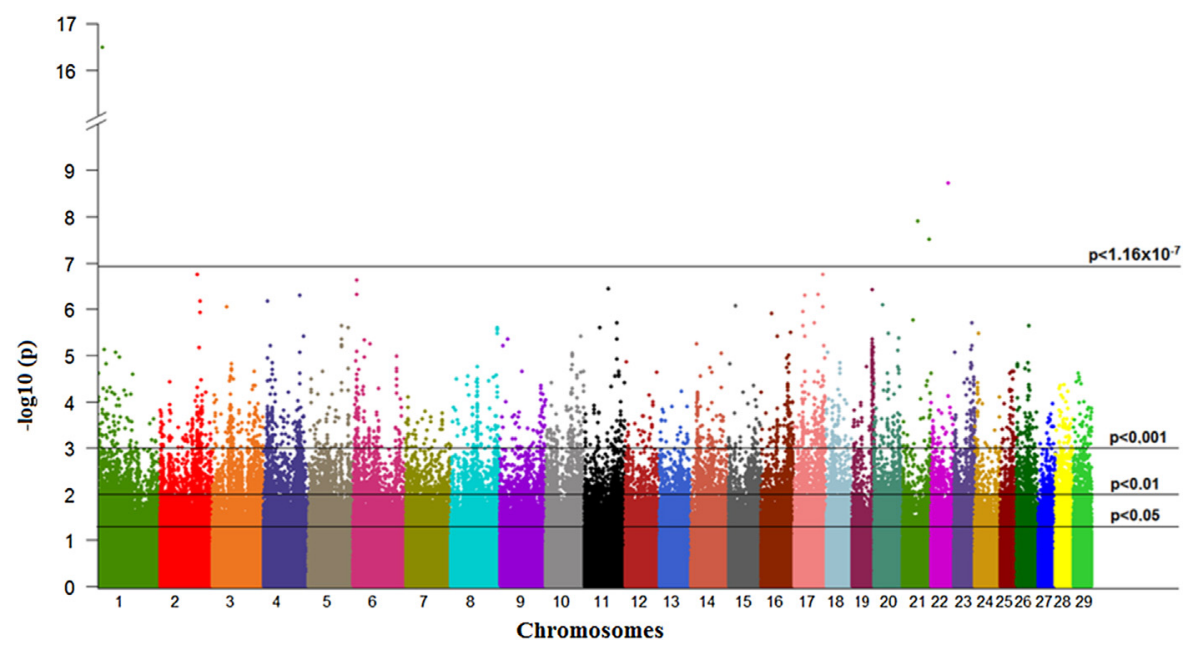

Fig. 4. Manhattan plot for early pregnancy; $-\log 10(P$-value $)$ is plotted as a function of SNPs per chromosome.

Table 4

SNPs and genes closest to the SNPs that were associated with age at first calving (AFC) and early pregnancy (EP) after Bonferroni correction ( $P$ value $\left.=1.16 \times 10^{-7}\right)$.

\begin{tabular}{lllllll}
\hline Trait & SNP & BTA & Position (bp) & P-value & Gene & Distance (bp) \\
\hline AFC & BovineHD0100003126 & 1 & 9816619 & $4.27 \times 10^{-18}$ & APP & 0 \\
& BovineHD0400002732 & 4 & 8853684 & $3.20 \times 10^{-8}$ & LOC100140224 & 8642 \\
& BovineHD0600002088 & 6 & 8937501 & $5.75 \times 10^{-8}$ & LOC526064 & 712370 \\
& BovineHD1100017335 & 11 & 60860824 & $8.97 \times 10^{-8}$ & TMEM17 & 54197 \\
& BovineHD1700018953 & 17 & 65795029 & $1.06 \times 10^{-7}$ & LOC100848089 \\
& BovineHD2100019377 & 21 & 66082472 & $4.28 \times 10^{-8}$ & SETD3 & 0 \\
EP & BovineHD2200012994 & 22 & 44861196 & $3.58 \times 10^{-9}$ & ARHGEF3 & 0 \\
& BovineHD0100003126 & 1 & 9816619 & $3.45 \times 10^{-17}$ & APP & LOC785745 \\
& BovineHD2100011237 & 21 & 38863958 & $1.30 \times 10^{-8}$ & SETD3 & 0 \\
& BovineHD2100019377 & 21 & 66082472 & $3.17 \times 10^{-8}$ & ARHGEF3 \\
\hline
\end{tabular}

SNP: Single nucleotide polymorphism; Position: Position of the SNP on the chromosome.

2016; Costa et al., 2015), using the same breed (Nascimento et al., 2015) and other beef cattle breeds (Akanno et al., 2015; Fortes et al., 2013a,b; Hawken et al., 2012; Fortes et al., 2012, 2011) didn't elucidate the same genomic regions/genes/significant SNPs for related reproductive traits (or even the same trait). Magalhães et al. (2016) analyzing meat quality traits in cattle had similar findings. Many hypothesis could arise from the present and previ- 
Table 5

Additive effects and dominance deviations of Bonferroni-adjusted significant SNPs for age at first calving (AFC) and early pregnancy (EP).

\begin{tabular}{|c|c|c|c|c|c|c|}
\hline Trait & SNP & Additive genetic effect (days) & $P$-value & Dominance deviation & $P$-value & Polymorphism \\
\hline \multirow[t]{7}{*}{ AFC } & BovineHD0100003126 & $15.74 \pm 9.32$ & 0.09 & $-22.46 \pm 10.91$ & 0.04 & $\mathrm{~A} / \mathrm{G}$ \\
\hline & BovineHD0400002732 & $25.07 \pm 19.97$ & 0.21 & $-30.09 \pm 21.14$ & 0.16 & $\mathrm{~T} / \mathrm{C}$ \\
\hline & BovineHD0600002088 & $4.77 \pm 13.15$ & 0.72 & $+33.28 \pm 15.55$ & 0.03 & $\mathrm{~T} / \mathrm{C}$ \\
\hline & BovineHD1100017335 & $25.06 \pm 20.98$ & 0.23 & $-34.18 \pm 23.48$ & 0.15 & $\mathrm{~T} / \mathrm{C}$ \\
\hline & BovineHD1700018953 & $-2.36 \pm 9.06$ & 0.90 & $+21.46 \pm 20.03$ & 0.28 & $\mathrm{~T} / \mathrm{G}$ \\
\hline & BovineHD2100019377 & $-13.44 \pm 6.28$ & 0.03 & $-32.98 \pm 9.44$ & 0.0005 & $\mathrm{~A} / \mathrm{G}$ \\
\hline & BovineHD2200012994 & $15.08 \pm 6.52$ & 0.02 & $-20.16 \pm 9.54$ & 0.04 & $\mathrm{~A} / \mathrm{C}$ \\
\hline \multirow[t]{4}{*}{ EP } & BovineHD0100003126 & $-0.08 \pm 0.03$ & 0.002 & $0.09 \pm 0.03$ & 0.03 & $\mathrm{~A} / \mathrm{G}$ \\
\hline & BovineHD2100011237 & $0.01 \pm 0.02$ & 0.69 & $0.12 \pm 0.03$ & $<0.0001$ & $\mathrm{~A} / \mathrm{G}$ \\
\hline & BovineHD2100019377 & $0.04 \pm 0.02$ & 0.054 & $0.09 \pm 0.03$ & 0.002 & $\mathrm{~A} / \mathrm{G}$ \\
\hline & BovineHD2200012994 & $-0.048 \pm 0.02$ & 0.02 & $0.08 \pm 0.03$ & 0.01 & $\mathrm{~A} / \mathrm{C}$ \\
\hline
\end{tabular}

SNP: Single nucleotide polymorphism.

ous results. The SNP significance could be affected by breed, SNP coverage, linkage disequilibrium, allelic frequency, and number of animals genotyped; but an important effect of statistical methodology and SNP treatment (windows of SNPs, SNP-by-SNP) also exists.

The additive effects and dominance deviations (Table 5) of Bonferroni-adjusted significant SNPs for AFC and EP were estimated using orthogonal contrasts. The magnitudes of additive effects (Table 5), expressed as units of the traits, represent the average change expected for the substitution of one allele for another. For example, Nellore females having the favorable allele at SNP BovineHD0400002732 would be expected to be on average 25 days younger at first calving, which represents more than one estrous cycle.

The SNPs BovineHD2100019377 and BovineHD0100003126 indicated there was an additive effect for AFC and EP, respectively, whereas SNP BovineHD2200012994 located on chromosome 22, indicated a significant effect for the two traits. These markers could be used in selection programs designed to reduce the AFC or to increase EP in heifers.

\section{Conclusions}

The average extent of linkage disequilibrium estimated in Nellore cattle indicate that the SNP chip is an effective technology to identify QTL regions across the genome. The SNPs were associated with age at first calving and early pregnancy, with some of the SNPs being significant for both traits. Candidate genes were indicated for further fine-mapping studies that would result in a greater understanding of the physiology aspects of these traits. The additive effects indicated the possibility of using these SNPs in marker-assisted selection as sexual precocity indicator traits in Nellore cattle.

\section{Conflict of interest}

No conflict of interest.

\section{Acknowledgements}

This research was supported by Fundação de Amparo à Pesquisa do Estado de São Paulo (Grant Numbers: 2009/16118-5 and 2010/13691-3). We thank Agropecuária
Jacarezinho Ltda. for providing the samples and the dataset used in this study.

\section{References}

Akanno, E.C., Plastow, G., Fitzsimmons, C., Miller, S.P., Baron, V., Ominski, K., Basarab, J.A., 2015. Genome-wide association for heifer reproduction and calf performance traits in beef cattle. Genome 58, 549-557.

Benjamini, Y., Hochberg, Y., 1995. Controlling the false discovery rate: a practical and powerful approach to multiple testing. J. Roy. Stat. Soc. 57, 289-300.

Beretta, V., Lobato, J.F.P., Mielitz Netto, C.G.A., 2001. Produtividade e eficiência biológica de sistemas pecuários de cria diferindo na idade das novilhas ao primeiro parto e na taxa de natalidade do rebanho no Rio Grande do Sul. Rev. Bras. Zootecn. 30, 1278-1286.

Beretta, V., Lobato, J.F.P., Mielitz Netto, C.G.A., 2002a. Produtividade e eficiência biológica de sistemas de recria e engorda de gado de corte no Rio Grande do Sul. Rev. Bras. Zootecn. 31, 696-706.

Beretta, V., Lobato, J.F.P., Mielitz Netto, C.G.A., 2002b. Produtividade e eficiência biológica de sistemas de produção de gado de corte de ciclo completo no Rio Grande do Sul. Rev. Bras. Zootecn. 31, 991-1001.

Boligon, A.A., Albuquerque, L.G., 2011. Genetic parameters and relationships of heifer pregnancy and age at first calving with weight gain: yearling and mature weight in Nelore cattle. Livest. Prod. Sci. $141,12-16$.

Boligon, A.A., Albuquerque, L.G., Mercadante, M.E.Z., Lobo, R.B., 2010. Study to relations between age at first calving, average weight gains and weights from weaning to maturity in Nellore cattle. Rev. Bras. Zootecn. 39, 746-751.

Brumatti, R.C., Ferraz, J.B.S., Eler, J.P., Formigonni, I.B., 2011. Desenvolvimento de índices de seleção em gado de corte sob enfoque de um modelo bioeconômico. Arch. Zootec. 60, 205-213.

Costa, R.B., de Camargo, G.M.F., Diaz, I.D.P.S., Irano, N., Dias, M.M., Carvalheiro, R., Boligon, A.A., Baldi, F., Oliveira, H.N., Tonhati, H., Albuquerque, L.G., 2015. Genome-wide association study of reproductive traits in Nellore heifers using Bayesian inference. Genet. Select. Evol. 47, 67.

De Roos, A.P.W., Hayes, B.J., Spelman, R.J., Goddard, M.E., 2008. Linkage disequilibrium and persistence of phase in Holstein-Friesian, Jersey and Angus cattle. Genetics 179, 1503-1512.

Dias, L.T., EL Faro, L., Albuquerque, L.G., 2004a. Efeito da idade de exposição de novilhas à reprodução sobre estimativas de herdabilidade da idade ao primeiro parto em bovinos Nelore. Arq. Bras. Med. Vet. Zoo. 56, 370-373.

Dias, L.T., EL Faro, L., Albuquerque, L.G., 2004b. Estimativas de herdabilidade para idade ao primeiro parto na raça Nelore. Rev. Bras. Zootecn. 33, 97-102.

Drouilhet, L., Lecerf, F., Bodin, L., Fabre, S., Mulsant, P., 2009. Fine mapping of the FecL locus influencing prolificacy in Lacaune sheep. Anim. Genet. 40, 804-812.

Eastell, R., 2005. Role of oestrogen in the regulation of bone turnover at the menarche. J. Endocrinol. 185, 223-234.

Eler, J.P., Silva, J.A.I.I.V., Ferraz, J.B.S., Dias, F., Oliveira, H.N., Evans, J.L., Golden, B.L., 2002. Genetic evaluation of the probability of pregnancy at 14 months for Nellore heifers. J. Anim. Sci. 80, 951-954. 
Eler, J.P., Silva, J.A.I.I.V., Evans, J.L., Ferraz, J.B.S., Dias, F., Golden, B.L. 2004. Additive genetic relationships between heifer pregnancy and scrotal circumference in Nellore cattle. J. Anim. Sci. 82, 2519-2527.

Espigolan, R., Baldi, F., Boligon, A.A., Souza, F.R., Gordo, D.M., Tonussi, R.L., Cardoso, D.F., Oliveira, H.N., Tonhati, H., Sargolzaei, M., et al., 2013. Study of whole genome linkage disequilibrium in Nellore cattle. BMC Genomics 14, 305-312.

Fortes, M.R., Reverter, A., Nagaraj, S.H., Zhang, Y., Jonsson, N.N., Barris, W., Lehnert, S., Boe-Hansen, G.B., Hawken, R.J., 2011. A single nucleotide polymorphism-derived regulatory gene network underlying puberty in 2 tropical breeds of beef cattle. J. Anim. Sci. 89, 1669-1683.

Fortes, M.R.S., Lehnert, S.A., Bolormaa, S., Reich, C., Fordyce, G., Corbet, N.J., Whan, V., Hawken, R.J., Reverter, A., 2012. Finding genes for economically important traits: brahman cattle puberty. Anim. Prod. Sci. 52, 143-150.

Fortes, M.R.S., Li, Y., Collis, E., Zhang, Y., Hawken, R.J., 2013a. The IGF1 pathway genes and their association with age of puberty in cattle. Anim. Genet. 44, 91-95.

Fortes, M.R.S., Kemper, S., Sasazaki, S., Reverter, A., Pryce, E., Barendse, W., Bunch, R., McCulloch, R., Harrison, B., Bolormaa, S., Zhang, Y.D., Hawken, R.J., Goddard, M.E., Lehnert, S.A., 2013b. Evidence for pleiotropism and recent selection in the PLAG1 region in Australian Beef cattle. Anim. Genet. 44, 636-647.

Fortes, M.R.S., Suhaimi, A.H.M.S., Porto-Neto, L.R., McWilliam, S.M., Flatscher-Bader, T., Moore, S.S., D’Occhio, M.J., Meira, C.T., Thomas, M.G., Snelling, W.M., Reverter, A., Lehnert, S.A., 2014. Post-partum anoestrus in tropical beef cattle: a systems approach combining gene expression and genome-wide association results. Livest. Sci. 166, 158-166.

Funston, R.N., Summers, A.F., 2013. Epigenetics: setting up lifetime production of beef cows by managing nutrition. Annu. Rev. Anim. Biosc. 1, 339-363.

Goddard, M.E., Hayes, B.J., 2009. Mapping genes for complex traits in domestic animals and their use in breeding programmes. Nat. Rev. Genet. 10, 381-391.

Grossi, D.A., Venturini, G.C., Paz, C.C., Bezerra, L.A., Lôbo, R.B., Oliveira, J.A., Munari, D.P., 2009. Genetic associations between age at first calving and heifer body weight and scrotal circumference in Nelore cattle. J. Anim. Breed. Genet. 126, 387-393.

Höglund, J.K., Guldbrandtsen, B., Su, G., Thomsen, B., Lund, M.S., 2009. Genome scan detects quantitative trait loci affecting female fertility traits in Danish and Swedish Holstein cattle. J. Dairy Sci. 92, 2136-2143

Hawken, R.J., Zhang, Y.D., Fortes, M.R.S., Collis, E., Barris, W.C., Corbet, N.J., Williams, P.J., Fordyce, G., Holroyd, R.G., Walkley, J.R.W., et al., 2012. Genome-wide association studies of female reproduction in tropically adapted beef cattle. J. Anim. Sci. 90, 1398-1410.

Hayes, B.J., Lien, S., Nilsen, H., Olsen, H.G., Berg, P., Maceachern, S., Potter, S., Meuwiswsen, T.E., 2006. The origin of selection signatures on bovine chromosome 6. Anim. Genet. 39, 101-105.

Hayes, B.J., 2009. Whole Genome Association and Genomic Selection. FUNEP, Jaboticabal, SP, 120p.

Hill, W.G., Robertson, A., 1968. Linkage disequilibrium in finite populations. Theor. Appl. Genet. 38, 226-231.

Irano, N., de Camargo, G.M.F., Costa, R.B., Terakado, A.P.N., Magalhães, A.F.B., Silva, R.M.O., Dias, M.M., Bignardi, A.B., Baldi, F., Carvalheiro, R., Oliveira, H.N., Albuquerque, L.G., 2016. Genome-wide association study for indicator traits of sexual precocity in nellore cattle. PLoS One, http://dx.doi.org/10.1371/journal.pone.0159502.

Khatkar, M.S., Nicholas, F.W., Collins, A.R., Zenger, K.R., Cavanagh, J.A.L., Barris, W., Schnabel, R.D., Taylor, J.F., Raadsma, H.W., 2008. Extent of genome-wide linkage disequilibrium in Australian Holstein-Friesian cattle based on a high-density SNP panel. BMC Genomics 9, 187-204

Krotz, S.P., Ballow, D.J., Choi, Y., Rajkovic, A., 2009. Expression and localization of the novel and highly conserved gametocyte-specific factor 1 during oogenesis and spermatogenesis. Fertil. Steril. 91, 2020-2024

Krupa, E., Wolfova, M., Peskovicova, D., Huba, J., Krupova, Z., 2005. Economic values of traits for Slovakian Pied cattle under different marketing strategies. Czech J. Anim. Sci. 50, 483-492.

Lu, D., Sargolzaei, M., Kelly, M., Li, C., Vander Voort, G., Wang, Z., Plastow, G., Moore, S., Miller, S.P., 2012. Linkage disequilibrium in Angus, Charolais and Crossbred beef cattle. Front. Genet. 3, 152-161.

Magalhães, A.F.B., de Camargo, G.M.F., Fernandes Junior, G.A., Gordo, D.G.M., Tonussi, R.L., Costa, R.B., Espigolan, R., Silva, R.M.O., Bresolin, T., Andrade, W.B.F., Takada, L., Feitosa, F.L.B., Baldi, F., Carvalheiro, R., Chardulo, L.A.L., Albuquerque, L.G., 2016. Genome-wide association study of meat quality traits in nellore cattle. PLoS One, http://dx.doi.org/10.1371/journal.pone.0157845.
Matukumalli, L.K., Lawley, C.T., Schnabel, R.D., Taylor, J.F., Allan, M.F. Heaton, M.P., O'connell, J., Moore, S.S., Smith, T.P.L., Sonstegard, T.S., Van Tassel, C.P., 2009. Development and characterization of a high density SNP genotyping assay for cattle. PLoS One 4, e5350, http://dx.doi.org/10.1371/journal.pone.0005350.

McElreavey, K., Fellous, M., 1999. Sex determination and the Y chromosome. Am. J. Med. Genet. 89, 176-185.

McKay, S.D., Schnabel, R.D., Murdoch, B.M., Matukumalli, L.K., Aerts, J., Coppieters, W., Crews, D., Neto, E.D., Gill, C.A., Gao, C., et al., 2007. Whole genome linkage disequilibrium maps in cattle. BMC Genet. 8, 74-85.

Mercadante, M.E.Z., Lobo, R.B., Oliveira, H.N., 2000. Estimativas de (co)variância entre características de reprodução e de crescimento em fêmeas de um rebanho Nelore. Rev. Bras. Zootecn. 29, 997-1004.

NCBI, 2013. National Center for Biotechnology Information, http://www.ncbi.nlm.nih.gov/projects/mapview/map_search.cgi?taxid =9913\&build=6.1/(Accessed 18 February 2013).

Nascimento, A.V., Matos, M.C., Seno, L.O.A.R.S., Romero, A.R.S., Garcia, J.F., Grisolia, A.B., 2015. Genome wide association study on early puberty in Bos indicus. Genet. Mol. Res. 15, 1

Pötter, L., Lobato, J.F.P., Mielitz Netto, C.G.A., 1998. Produtividade de um modelo de produção para novilhas de corte primíparas aos dois, três e quatro anos de idade. Rev. Bras. Zootecn. 27, 613-619.

Pötter, L., Lobato, J.F.P., Mielitz Netto, C.G.A., 2000. Análises econômicas de modelos de produção com novilhas de corte primíparas aos dois, três e quatro anos de idade. Rev. Bras. Zootecn. 29, 861-870.

Pereira, E., Eler, J.P., Ferraz, J.B.S., 2000. Correlação genética entre perímetro escrotal e algumas características reprodutivas na raça Nelore. Rev. Bras, Zootecn. 29, 1676-1683.

Pereira, J.C.C., Ribeiro, S.H.A., Silva, M.A., Bergmann, J.A.G., Costa, M.D., 2005. Análise genética de características ponderais e reprodutivas de fêmeas bovinas Tabapuã. Arq. Bras. Med. Vet. Zoo. 57, 231-236.

Pryce, J.E., Bolormaa, S., Chamberlain, A.J., Bowman, P.J., Savin, K., Goddard, M.E., Hayes, B.J., 2010. A validated genome-wide association study in two dairy cattle breeds for milk production and fertility traits using variable length haplotypes. J. Dairy Sci. 93, 3331-3345.

Regatieri, I.C., Boligon, A.A., Baldi, F., Albuquerque, L.G., 2012. Genetic correlations between mature cow weight and productive and reproductive traits in Nellore cattle. Genet. Mol. Res. 11, 2979-2986.

Sahana, G., Guldbrandtsen, B., Bendixen, C., Lund, M.S., 2010. Genome-wide association mapping for female fertility traits in Danish and Swedish Holstein cattle. Anim. Genet. 41, 579-588.

Sambrook, J., Fristch, E.F., 1989. Molecular Cloning A Laboratory Manual, 2nd edn. Cold Spring Laboratory, New York.

Sargolzaei, M., Schenkel, F.S., Jansen, G.B., Schaeffer, L.R., 2008. Extent of linkage disequilibrium in holstein cattle in North America. J. Dairy Sci. 91, 2106-2117.

Shiotsuki, L., Silva, J.A.V., Tonhati, H., Albuquerque, L.G., 2009. Genetic associations of sexual precocity with growth traits and visual scores of conformation, finishing, and muscling in Nelore cattle. J. Anim. Sci. 87, 1591-1597.

Silva, J.A.I.I.V., Dias, L.T., Albuquerque, L.G., 2005. Estudo genético da precocidade sexual de novilhas em um rebanho Nelore. Rev. Bras. Zootecn. 34, 1568-1572.

Silva, C.R., Neves, H.H.R., Queiroz, S.A., Sena, J.A.D., Pimentel, E.C.G., 2010. Extent of linkage disequilibrium in Brazilian Gyr dairy cattle based on genotypes of AI sires for dense SNP markers. In: Proceedings of the 9th World Congress on Genetics Applied to Livestock Production, Leipzig, Germany. 1-6 August.

Van Melis, M.H., Eler, J.P., Rosa, G.J.M., Ferraz, J.B.S., Figueiredo, L.G.G., Mattos, E.C., Oliveira, H.N., 2010. Additive genetic relationships between scrotal circumference, heifer pregnancy and stayability in Nellore cattle. J. Anim. Sci. 88, 3809-3813.

Venkataramani, V., Rossner, C., Iffland, L., Schweyer, S., Tamboli, I.Y., Walter, J., Wirths, O., Bayer, T.A., 2010. Histone deacetylase inhibitor valproic acid inhibits cancer cell proliferation via down-regulation of the Alzheimer amyloid precursor protein. J. Biol. Chem. 285, 10678-10689.

Wolfova, M., Wolf, J., Zahradkova, R., Pribiyl, J., Dano, J., Krupa, E., Kica, J., 2005. Breeding objectives for beef cattle used in different production system. 2. Model application to production system with the Charolais breed. Livest. Prod. Sci. 95, 217-230.

Zhang, Y.D., Tier, B., Hawken, R.J., 2010. Whole genome analysis of heifer puberty in brahman cattle. In: Proceedings of the 9th World Congress on Genetics Applied to Livestock Production, Leipzig, German. 1-6 August. 